\title{
Social use of alcohol among adolescent offenders: a fundamental approach toward human needs
}

\author{
USO SOCIALIZADO DE ÁLCOOL POR ADOLESCENTES OFENSORES: UM ENFOQUE \\ FUNDAMENTADO NAS NECESSIDADES HUMANAS
}

USO SOCIALIZADO DEL ALCOHOL POR ADOLESCENTES INFRACTORES: UN
ENFOQUE FUNDAMENTADO EN LAS NECESIDADES HUMANAS

Gustavo D'Andrea', Carla Aparecida Arena Ventura², Moacyr Lobo da Costa Júnior ${ }^{3}$

\begin{abstract}
This study examined some basic health care approaches toward human needs, with a particular focus on nursing. We aimed to incorporate these approaches into the discussion of the mental health of adolescent offenders who consume alcohol. We discuss specific needs of the delinquent group, critique policies that prioritize coercion of adolescent offenders, and the role that nurses could play in the sphere of juvenile delinquency.
\end{abstract}

\section{DESCRIPTORS}

Adolescent

Juvenile delinquency

Alcohol-related disorders

Adolescent health services

Health Services Needs and Demand

Nursing

\section{RESUMO}

No presente artigo, nosso objetivo é visitar algumas considerações básicas sobre necessidades humanas na área da saúde, procurando afunilar a perspectiva no prisma específico da Enfermagem, e trazê-las ao centro da discussão sobre a saúde mental do adolescente ofensor usuário de álcool. Esta tarefa abrange uma discussão sobre necessidades específicas concebidas em ambiente grupal delinquente, uma crítica a políticas que priorizam a coerção sobre adolescentes ofensores e uma análise do papel que o enfermeiro pode desempenhar no âmbito da delinquência juvenil.

\section{DESCRITORES}

Adolescente

Delinquência juvenil

Transtornos relacionados ao uso de álcool

Serviços de saúde para adolescentes

Necessidades e Demandas de Serviços de Saúde

Enfermagem

\section{RESUMEN}

El objetivo de este artículo es visitar algunas consideraciones básicas sobre las necesidades humanas en el área de la salud, procurando profundizar la perspectiva en el prisma específico de la Enfermería y traerlas al centro de la discusión sobre la salud mental del adolescente infractor usuario del alcohol. Esta tarea abarca un debate sobre las necesidades particulares concebidas en el ambiente del grupo delincuencial, una crítica a las políticas que dan prioridad a la coerción sobre los adolescentes infractores y un análisis del rol que puede desarrollar el enfermero en el ámbito de la delincuencia juvenil.

\section{DESCRIPTORES}

Adolescente

Delincuencia juvenil

Trastornos relacionados con alcohol Servicios de salud para adolescentes Necesidades y Demandas de Servicios de Salud Enfermería

${ }^{1}$ Doctoral Student in Science, Psychiatric Nursing, Escola de Enfermagem de Ribeirão Preto, Universidade de São Paulo, Ribeirão Preto, SP, Brazil. ${ }^{2}$ Professor, Ph.D. Escola de Enfermagem de Ribeirão Preto, Universidade de São Paulo, Ribeirão Preto, SP, Brazil. caaventu@gmail.com ${ }^{3}$ Professor, Ph.D. Escola de Enfermagem de Ribeirão Preto, Universidade de São Paulo, Ribeirão Preto, SP, Brazil. 


\section{INTRODUCTION}

Human needs are a crucial point in the global discussion on development ${ }^{(1)}$. The international fundamentals of the juvenile justice system are also important for national development ${ }^{(2)}$. Juvenile delinquency that involves offenses by adolescents users of alcohol and other substances is not just a violation issue; it is also primarily a health issue that could affect the physical and mental integrity of the offender, his/her family, and society.

Cultural conformation to a social subgroup can result in the formation of desires that an individual perceives as needs; the individual seeks to fulfill that need in order to become a member of the group, even in a manner that entails violence. In this sense, it is right that several external factors (such as family, community, and culture), interrelated with biologic factors and other individual elements, could contribute to a predisposition toward aggression ${ }^{(3)}$. In addition, group influence is a risk factor with an important role in adolescents' participation in drug use and infractions ${ }^{(4)}$. When considering careers in organized crime, in some cases the delinquency can be considered as reflecting a way of life based on psychoactive substance abuse and thereby based on a self-affirmation structure amid relationships of power and violence. We are not stating that microsocial context is isolated from a wider economic and social context but rather that it is characterized by a self-identity or official stigmatized behavior. Groups are represented as cases for the police, especially in poor neighborhoods of large urban areas.

The role of health care in the face of violence has become very relevant. Currently, it is not just the institutions for judgment or repression (judicial institution, police, correctional offices, military) that are considered responsible; health professionals also have the potential to make a wide impact on research into and prevention of violence and the defense of rights, particularly health providers who support victims of violence ${ }^{(3)}$.

A step forward would be also to consider the role of health care in viewing the offender as both criminal and victim at the same time. Therefore, it is important to discuss conceptions of needs in order to reflect on how to focus on the mental health of adolescents offenders who use drugs and alcohol.

Our aim was to examine some basic health approaches toward human needs, with particular focused on the nursing perspective, and to incorporate these approaches into the discussion about the mental health of adolescent offenders who consume alcohol. We discuss specific needs of the delinquent group, critique policies that prioritize coercion of adolescent offenders, and the role that nurses could play in the sphere of juvenile delinquency.
References to reports published in other languages and quotations thereof were translated by the authors of this study.

\section{HUMAN NEEDS IN HEALTH: ADMINISTRATION'S VIEW}

When looking at the adolescent offender from the point of view of mental health promotion, we face the issue of human needs. There are many reasonable questions, such as, Who defines/determines what are needs, and what needs should be supported by the State?; Does the State have the right to impose that citizens receive what has been determined as adequate to address their needs?; Does the State address human needs sufficiently such that people are enabled to live fully? These questions make sense in the area of juvenile delinquency because when the adolescent's behavior lasts for a long time and the context for that behavior is organized crime, the strength of the group challenges the official legal order. There are norms and commitments inside delinquent groups that unify their members with bounds stronger than those stimulated by global, human rights.

The following paragraphs will provide a basic framework for conceptions on human needs in the health area to provide a wider perspective on the subject.

The aim of this exposition is to compare expectation conceptions seen as needs of adolescents with delinquent behavior and views on needs that are involved in violent behavior as a mean of satisfaction. Robison and Elkan ${ }^{(5)}$ endorsed consideration of the assessment process for needs in health by reviewing a variety of approaches toward defining needs. They referred three set of approaches. The first, proposed by Jonathan Bradshaw, classified needs as normative, felt, expressed, and comparative. A normative need is defined by an expert, a professional, or an administrator in specific situations and is subjected to the knowledge and values of each moment. The felt need, which does not reflect the real need, is equivalent to $a$ want; it refers to situations in which people do not recognize that they have a need or in which they think there is a need but in reality there is not. The expressed need is the felt need transformed into action or what economists call demand for service; this is also not a reflection of a real need. Finally, the comparative need is found by the study of characteristics of those who are already receiving a service in a way that a person needs something; if someone with similar characteristics to others is not receiving the same service, this definition could be used to assess both individual and group needs.

In a second approach, Robinson and Elkan ${ }^{(5)}$ refer to Len Doyal and Ian Gough's objective definition of need, which is opposed to a purely subjective and relative conception. According to this definition, there are objective needs that are common to all-that is, they are universal.
Social use of alcohol among adolescent offenders: a fundamental approach toward human needs D'Andrea G, Ventura CAA, Costa Júnior ML 
Complete participation in society is the definitive objective of all human beings and, for this reason, there are two basic needs to be addressed: the need for physical health and the need for autonomy. These two needs are fundamental rights of all human beings. Along with basic needs, there are also intermediary needs that are equally universal and objective; both types of needs could be addressed in a wide variety of ways. It is suggested that experts and lay people must be responsible for deciding whether a policy is efficient for both basic and intermediary needs; these people should confront each other to reconcile differences in their approaches.

A third approach mentioned by Robinson and Elkan ${ }^{(5)}$ is the economists' point of view. The economists' approach is relative; it states the existence of objective needs and that persons do not have any type of moral right of having their needs satisfied. In addition, it reject these beliefs as emotive and of little help. Economists prefer to speak of deprivation, demand, and preferences, although they admit that to speak about needs in a health service context (referring to the Gavin Mooney statement), it is not always that consumers have complete information on their health status and availability of services. Sometimes physician and nurses, part of the elite body of health, are in a better position than the individual receiving treatment to decide what needs he/she must pursue.

Gavin Mooney affirmed that because resources are scarce, economists of health emphasize that needs must be categorized in order of priority, and difficult choices must be made to address a need in spite of another. It is concluded that the most important contribution of economists for debate on 'needs' is their insistence on which needs cost money, and for this reason, the related costs of satisfaction of different needs must be investigated ${ }^{(5)}$.

We verified in the three groups of approaches some common points: the assessment aspect, concerning human needs considered in the realm public administration. This assessment that is closed to its own concept or concerning to the efficacy of respective politics, and the fact that each assessment can reflect the State's activity with regard to needs satisfaction. However, a data point that cannot be ignored is the fact that for people under age of 18 years, Brazil( ${ }^{(6)}$ has adopted the United Nations' formal position on the economic, social, and cultural rights of children in exhaustively applying resources to implement these rights. No matter the theory adopted by public administrators concerning the definition of what needs are, if those needs are of children and adolescents, the discussion on costs of their satisfaction is mitigated.

We also perceived indirect mention of the theme of artificial needs, and we believe that this is more important than the health needs that the State proposes to address, mainly because of the fundamental relevance of dynamic comprehension of needs for the State to take correct action when facing them.
How can nursing be included in this theme, and how can this question contribute to the view of juvenile delinquency associated with substance use?

We believe that nursing can play an important role in addressing human needs. A focus on needs is especially relevant to nursing as it evolves from a biomedical model to a focus on human as multifaceted beings (with biological, psychological, social, and spiritual components) rather than just on the disease or illness ${ }^{(7)}$. We elaborate on this discussion in the following paragraphs.

\section{SHARED NEEDS AND HOMEOSTASIS}

In Brazil, the work of Wanda de A. Horta on human needs in the nursing arena is well known. Given the interdisciplinary aspect of the theme evaluated in our study, we highlight a more delimited position for our own purposes based on Cianciarullo's ${ }^{(8)}$ observation, which focus on social issues, a position more deeply examined by Potyara Pereira ${ }^{(9)}$. Therefore, in terms of human needs in nursing, the guidelines that Cianciarullo ${ }^{(8)}$ attributed to Horta, concerning needs and their relation with homodynamic imbalances, are supported by comments discussed further in this article, with consideration of other authors' statements ${ }^{(10)}$. Cianciarullo ${ }^{(8)}$ also cites Potyara Pereira, emphasizing her social and critical stance against the conception of social minimum, a term considered to be inferior to basic because of a biased approximation of meanings in political decision-making processes.

In the work of Pereira ${ }^{(9)}$ on human needs, we perceived an emphasis on social care. It is clear the link of question with thematic reference to conventional pondered and standardized, ethical commandments and citizenship adopted around the world and declared in the current Brazilian Constitution; in addition, we observed a kind of dependence in the management of needs toward situations of deprivation, which was also seen in Cianciarullo's ${ }^{(8)}$ paper and in the view of economists that we mentioned above.

Therefore, Pereira criticized the ideal of the social minimum presented in the Organic Law of Social Assistance $\left(\right.$ LOAS $\left.^{(11)}\right)$, emphasizing its difference from the concept of basic needs. Minimum and basic are presented as different concepts; the first implies a reduction, and the second implies something that is fundamental. According to the author, this difference will have practical consequences because an emphasis on minimum needs leads to policies of care cuts (a common concern among liberals), whereas the idea of basic concerns policies resulting in services of higher quality, scope, and optimization.

At a wider perspective, as presented above, we could affirm that it is difficult to assimilate the theme of human needs, especially with regard to social rights and the duty of the State. However, a more limited field of analysis is provided by approaching the health of adolescent offend- 
ers who use alcohol. In the current study, this was considered a deviant behavior with social relevance.

A fraction of deviation acts of adolescents appear as agent provocateurs of state coercive action, whereas a greater number are absorbed by society without requiring official reaction from the State. The problem is that in these particular circumstances the deviant behavior is formally declared using an occurrence report. This report induces a violation process that results in a sentence (that is, legal judgment). We consider this a problem because juvenile delinquency associated with substance use reflects the dynamic context of human needs. Therefore, it is a health issue (protective, rehabilitation) that the State has converted to an issue of law enforcement, which in case of adolescents could be considered as negative, punitive, and stigmatized.

To support our discussion, we refer to basic notions on homeostasis and its relation to human needs according to the nursing point of view. A brief introductory phrase concerning what would be the fundamental determination of the corresponding tasks of homeostasis as a basic concept for the nursing process to be suggested as principle for approaching the theme of needs is: to determine the needs we share as humans and in what degree such needs are addressed ${ }^{(10)}$.

As stated by Ellis and Nowlis(10), from the first use of the term homeostasis in 1926 by W. B. Cannon to the wider and updated view shared by M. E. Rogers in 1970, there has been a change in pespective from more specific definition, i.e., physicological, of homeostasis for a more inclusive one, of homeodynamic, which is accepted by Ellis and Nowlis (although they prefer the use of the old term). The newer definition incorporates an emotional aspect; in other words, the emotional life is included in the explication of homeostasis as being the tendency of all living tissue toward recovery and keeping itself in a balanced condition, wherein for living tissue, the brain is considered the center of emotional life. In this view homeostasis is applied to psychological processes.

When reporting on human needs, Ellis and Nowlis(10) mentioned authors such as Abraham Maslow and Carl Rogers, emphasizing the categorization of hierarchy of human needs (Maslow) and the theory of need for full functioning (Rogers). Ellis and Nowlis also highlight that for nursing the hierarchy proposed by Maslow is interesting in general, but according to Rogers' approach, a fundamental topic is the sensibility and empathic belief that nurses have needs that must be met in order for them to provide healthcare efficaciously.

Ellis and Nowlis also emphasize that in all cases, patient care will be always based on physical and psychological safety, which involves practicing in good organization that espouses local care, honesty, confidentiality, and ethical behaviorln the explanation-rich context of human needs with relation to nursing, we emphasize the topic of psychosocial needs as a framework for discussing juvenile delinquency associated with substance use ${ }^{(10)}$.Psychosocial needs include the need of identity, good mental health, and system of values and believes; to address these needs requires psychosocial skills by the nurse, and such skills are among the first that you must acquire to interact effectively with colleagues on the care team and with patients/clients. A study focusing of family health ${ }^{(12)}$ emphasized the importance of intersubjectivity in the ambit of the approach toward health needs.

With regard to psychosocial needs, the following are highlighted: communication needs, which involve understanding situation and answering the patients' questions and are addressed by a health-teaching role for nurses emphasizing that a basic factor of health-teaching is the receptivity of patient and his/her willingness to learn; the need for complete development throughout the lifecycle, including physical and psychological aspects (that is, the need to go forward as life goes in homeostatic balance is a universal need; the need to achieve a social, cultural, and ethnical identity: This gives us a sense of belonging. It enables us to connect with a significant past and to be different. It also encourages us to feel a part of a group of people with a similar history of life. To be recognized as having a social, cultural or ethnical identity is a prerequisite to sharing such an identity with others in constructive way). In other words, this is a mental health need; according to Ellis and Nowlis: Inside hospital dependencies, small but significant pathways could be found to support the self-esteem and help to balance anxiety and depression. The maintenance of privacy, the inclusion of the patient in the decision process, and the recognition of patients as sensible people with feelings-all these could help to build patients' self-esteem. Offering patients attention indicates that To me you are an important person and also a patient; the need for a self-determined system of values and beliefs, with consideration of identity affirmation, well-being, and life; the need for sexual identity ${ }^{(10)}$.

The material on Ellis and Nowlis's ${ }^{(10)}$ thinking reflects serious, scientific, objective, and ethical content. However, one cannot deny the beauty and lyricism of details involved in rebalance of homeostasis. Our approach to social substance use seeks to reveal that in the empathic view of nurses toward adolescent offenders, such a rebalance is possible and that law enforcement can serve to frustrate efforts in this direction.

\section{ADOLESCENT OFFENDERS AND SOCIAL USE OF SUBSTANCES}

The catastrophic results of the Second World War led to the creation of the United Nations (UN), with its mission to guarantee human rights around the world. The creation of this body symbolizes an intellectual and
Social use of alcohol among adolescent offenders: a fundamental approach toward human needs D'Andrea G, Ventura CAA, Costa Júnior ML 
physical fight that had as its main focus the future of humanity. Humanity is now considered an innate attribute of persons that deserves immediately defense. Therefore, as highlighted by what we observed in this study, and inspired by Ellis and Nowlis ${ }^{(10)}$, the first step to approaching human needs of adolescent offenders is to remember that there is a need that we share as humans.

Attention on shared human needs should not depend on an individual's legal status. No matter the gravity or hideousness of a person's actions, the Brazilian legal system does not accept in any circumstance a state's reaction based on the privation of some needs, such as nutrition and hygiene, a respectful and dignified environment, and even intimate relationships. Nevertheless, to provide mental health attention to adolescents without allowing them to supply their needs found during groups' encounters would be insufficient. Similarly, the initial view of juvenile delinquent behavior should change. Switching from the violation view (which considers the offensive behavior to be the object of interest of the oppressive state power, shown by reactions of police and legal officers that limit rights) to a mental health view based on homeostasis rebalance could help achieve two goals: (1) to encourage the offender's the self-awareness that his/her behavior is violent and harmful to themselves, their family, and the community, to help the offender understand that the state recognizes the existence of freedom to make choices that contribute to their health. Also, to comprehend the many components that make up society; this activity should involve knowledge (and skills) and should be done with political autonomy. These requisites show how difficult, and probably frustrating, it is to approach this subject.

The proposal to understand the adolescent offender who uses alcohol or drugs involves consideration of violence that society hides as well as the efforts that the adolescent performs to self-affirm within a context. Most of violence occurs in places that are out of public view, such as at home or in a health institution, and victims are usually unwanted because they are too young or sick ${ }^{(3)}$.

Delinquent groups are strong creators of conventions and means that are supposed to satisfy someone' needs. A study conducted by the Pan American Health Organization $(\mathrm{PAHO})^{(3)}$ reported a concern with the youth gang phenomenon; it classified all gang formation such attributes as a basic of belonging to a group and creating an identity and a complex interaction of factors that lead young people to opt to live in gangs. This seems to proliferate at places without social order, and where no alternative forms of cultural shared behavior are provided ${ }^{(3)}$.

The study pointed out other socioeconomic, community, interpersonal factors that can contribute to youth participation in gangs:

lack of opportunity of social or economic mobility within

a society that aggressively promotes consumption; the decline of compliance with law and local plan order; school dropouts combined with low salaries for nonqualified jobs; the lack of guidance, supervision or support of parents and other family members; severe physical punishment or victimization at home; and the fact of having friends who already took part in gangs ${ }^{(3)}$.

Deprivations demonstrate needs, but these are not always the most adequate needs or even real needs at all; however they are sometimes strong enough to lead individuals to act violently.

Because of the precarious social meaning of contemporary culture, the subject attempts to find new ways to establish social bounds and searches for some collective. To participate in a gang or a criminal group offers those facing this symbolic deprivation a promise of social meaning, as a community illusion. The subject is submitted to narcissist ideals imposed by the local culture. In fact, the power of these groups exists because the subject attributes them the power, as a function of this symbolic deprivation, i.e., facing he/she precarious subjective consistency ${ }^{(13)}$.

However, the adequacy of needs must be considered on the basis of health and peace, and the dignity that is considered a global human right, taking into account the common good and the development and harmony of individuals. Microcontextualized situations could lead to the belief that any need directly linked to a tentative solution of a conflict is an adequate one. Considering the fact that there are conventions represented by the posed right that formalize expectations of human rights protection, it is possible that young people may believe marginal or illegal systems are the perfect environment to resolve their deprivation and achieve their expectations. Perhaps we can call these criminal needs; however, this concept requires a deep analysis involving adolescents. The distinction between basic needs and needs created in an isolated and violent environment must be the fact that some practices become part of a way of life for marginalized adolescents (for example the act of drug use).

Some authors ${ }^{(14)}$ faced a similar problem in reporting their experience with at-risk and socially vulnerable young people, which focused on improper use of psychoactive substances. They affirmed the need to accept the challenge to deal not only with negative aspects of the substance use, but also with the positives. Therefore, this is not the case to include, a priori, the question of substance use as being responsible for the behavior, but it is important to understand the behavior, considering that the use of drugs is part of a context and of the history of society. They were used in rituals, at parties, at leisure time, contrasting with or participating in other aspects of life in the society ${ }^{(15)}$. Hence, studies should discern the different social contexts of psychoactive substance use.

Cultural production related to delinquent groups can be expressed in daily life, wishes, relations, and values, as stated in the literature ${ }^{(16)}$ when describing funks (type 
of music) about soccer fans and criminal factions, which denote that its content is linked to some type of conflict (for example, conflict of police with other factions), and often express needs. A study ${ }^{(17)}$ analyzed 50 funks songs of specific factions and identified seven categories of central themes in these songs: external conflicts of faction (again, conflicts of police with other factions), norms of behavior, affirmation of faction identity, affirmation of warrior identity, consumption and demonstration of power, use of drugs, and difficulties faced in criminal life. These are not simple songs because there are group structures that impose norms existing in parallel to the current official legal order. It is also possible to refer to a system of criminal justice that agrees with the ethics and laws of the crime world and is perceived as part of the context of a specific community with wide norms (not applying just to participants with criminal behavior) ${ }^{(18)}$.

During the field research for the doctorate thesis Alcohol use and juvenile delinquency at the City of Ribeirão Preto (developed in the Psychiatric Nursing Program of Escola de Enfermagem de Ribeirão Preto, Universidade de São Paulo), we observed a significant allusions about social use of alcohol among adolescent offenders prosecuted by the state because of their behavior. In this case, social use is revealed as a habitual consumption of alcohol, purchased despite the legal prohibition of selling alcohol to minors, with friends (without the presence of family members) during leisure time. In correlating such consumption with identified aspects in groups with delinquent behavior, we pose the same questions as Heim ${ }^{(19)}$ : Does the use/abuse of alcohol and illicit drugs induce criminal behavior, or are adolescents with behavior problems more likely to use drugs? What factors maintain and contribute to escalation of delinquent activities?

This paper does not aim to answer these questions, but it is important to state them because they are relevant and justify the pondering on the nurse's public role in dealing with juvenile delinquency associated with alcohol use.

\section{DISCUSSION: NURSING ROLE FACING ADOLESCENTS NEEDS}

The behavior of adolescent offenders could certainly be viewed through the prism of need. Based on this point of view, we focus the reflection on the role of psychiatric nurses, whose direct and priority dealing with such individuals can lead to substantial social gains. An adolescent involved in crime and who self-identifies with the social use of alcohol would be motivated by physiological and psychological needs that are typically found in groups that they belong to, even though those behaviors are damaging their global health and are unwanted and supposedly dangerous to society. These needs can be called negative deviation needs, a term that we suggest on the basis of a study that sought to understand undesirable deviation behavior ${ }^{(20)}$. The main characteristic of these negative deviation needs is destructivity, influenced in negative form, for example, in normal development (complete and progressive) throughout the lifecycle (which is one of psychosocial needs $)^{(10)}$. Therefore, in this sense, negative deviation needs would be needs created by groups, intimately linked to negative/undesirable deviation behavior, that are fed back from a homeostasis imbalance and are of a progressively destructive character.

Therefore, we define the behavior issue of that adolescent (offender, alcohol user) within the context of a physical and psychosocial imbalance, and we pose the hypothesis that nurses can be inserted into this multifaceted task as a fundamental human resource for global health. As a consequence, nurse may help restore homeostasis in such individual. This point of view elevates the view toward adolescents health and in this sense to include the priority view on responsibility of the state on how to deal with adolescents presenting more severe deviant behavior. It also has implications for widening of covering and valorization of active search, which is extremely important in groups using substances ${ }^{(21)}$.

The position stated in this article is not a new approach but a next step to be taken. Juvenile delinquency should be considered a public health issue. We believe that nurses are strategic in this area, but these professionals do not fully understand the wide range of their role in this area. Perhaps this lack of knowledge stems from social, media, and bureaucratic influences. In ethical and legal terms, nursing already has autonomy and a sociopolitical role to take a step forward in this regard. For this reason, the advance of the discussion on needs seeks to demonstrate that other needs exist beyond those considered legitimate and acceptable and that response of states concerning delinquency should consider the strength of parallel bounds that are created in local cultures. Perhaps the greater the state omission, the higher the parallel bounds; however the functioning of human relations seems to be systematically ignored, and it seems that only the external behavior is considered in the process for punishment adopted by states. The state's reaction to juvenile delinquency, depending on how it is seen, could be stigmatizing and could violate human rights, even if, technically, punishment of adolescents is not allowed in Brazilian protection systems.

\section{FINAL CONSIDERATIONS}

Human's basis is the accumulated scientific reflection and the experience from global history that has been teaching the world about how to be. We do not deny the existence of barriers of diverse forms and sources, but we restate that more often the humanization view is becoming consolidated in mental health and slowly by dialogue among the disciplines that includes it will be included among more diverse themes of politic interest.
Social use of alcohol among adolescent offenders: a fundamental approach toward human needs D'Andrea G, Ventura CAA, Costa Júnior ML 
Nurses should be considered a fundamental part of the coordination of efforts within any discussion on the politics involving adolescent offenders. The inclusion of nurses in such discussions is important because they involve coordination from different areas, but in particular from health and social sciences.

The issue of human needs is the center and principle of this view, which leads to place the violation issue in second plan with the advantage to destipificar the behavior (i.e, not to categorize it in face of the law, and not to restrict it by age), which will widen the state's view on deviant behavior of those under 18 years old. Therefore, we also advocate for a nursing role in research and policies that seek to advance national development. A focus on human needs presents an updated, more human way to look at unhealthy behavior when it becomes antisocial behavior.

To see the deviant behavior of adolescents from a health viewpoint gives us direction to propose a structural

\section{REFERENCES}

1. Streeten P, Burki SJ, Hicks N, Stewart F. First things first. Oxford: Oxford University Press; 1982.

2. United Nations. United Nations Standard Minimum Rules for the Administration of Juvenile Justice ("The Beijing Rules") [Internet].1985 [cited 2012 Sept 11]. Available from: http:// www.unodc.org/pdf/criminal_justice/UN_Standard_Minimum_Rules_for_the_Admin_of_Juvenile_Justice_Beijing Rules.pdf

3. Organización Panamericana de la Salud; Organización Mundial de la Salud. Informe mundial sobre la violencia e la salud [Internet] Washington: OPAS/OMS; 2003 [citado 2012 set. 11]. Disponível em: http://www.paho.org/spanish/am/pub/ violencia_2003.htm

4. Martins MC, Pillon SC. A relação entre a iniciação do uso de drogas e o primeiro ato infracional entre os adolescentes em conflito com a lei. Cad de Saúde Pública. 2008; 24(5):1112-20.

5. Robinson J, Elkan R. Health needs assesment: theory and practice. New York: Churchill Livingstone; 1996.

6. Brasil. Decreto n. 99.710, de 21 de novembro de 1990. Promulga a Convenção sobre os Direitos da Criança [Internet]. Brasília; 1990 [citado 2012 set. 11]. Disponível em: http://www.planalto.gov.br/ccivil_03/decreto/1990-1994/D99710.htm

7. Amante LN, Rossetto AP, Schneider DG. Nursing care systematization at the Intensive Care Unit (ICU) based on Wanda Horta's theory. Rev Esc Enferm USP [Internet]. 2009 [cited 2013 Apr 24];43(1):54-64. Available from: http://www.scielo. br/pdf/reeusp/v43n1/en_07.pdf realignment of the theme inside the administrative-political structure: to dislocate the theme by no longer treating it (in practice) as a punishment or a public safety issue, and instead to include it in a structure of social security (which includes health with social assistance) that guarantees the present and future prosperity of society. The deviation behavior of adolescents should be placed in focus as part of the reference for their future.

We present the possible ways to address the political applicability of conceptions formed around homeostasis of adolescent offenders, who is considered an offender because he/she practiced an offensive action directed against someone else's rights, but in reality that person is a young citizen who needs a more effective attention to his/her rights. Futher studies are should assess deviation behavior and substance use, focusing on the nursing role at the center of a interdisciplinary dynamic in research and public policies for the mental health of the child and adolescent.

8. Cianciarullo TI. Necessidades humanas e saúde. In: Cianciarullo TI, Cornetta VK, organizadoras. Saúde, desenvolvimento e globalização. São Paulo: Ícone; 2002. p. 237-48.

9. Pereira PAP. Necessidades humanas: subsídios à crítica dos mínimos sociais. 6a ed. São Paulo: Cortez; 2011.

10. Ellis JR, Nowlis EA. Nursing: a human needs approach. 3rd ed. Boston: Houghton Mifflin; 1985.

11. Brasil. Lei 8.742, de 7 de dezembro de 1993. Dispõe sobre a organização da Assistência Social e dá outras providências [Internet]. Brasília; 1993 [citado 2013 fev. 27]. Disponível em: http://www.planalto.gov.br/ccivil_03/leis//8742.htm

12. Silva AMN, Mandú ENT. Abordagem de necessidades de saúde no encontro assistencial de trabalhadores e usuários na saúde da família. Texto Contexto Enferm [Internet]. 2012 [citado 2013 fev. 27];21(4):739-47. Disponível em: http:// www.scielo.br/pdf/tce/v21n4/03.pdf

13. Guerra AMC, Moreira JO, Lima NL, Pompeo BDS, Soares CAN, Carvalho LMS, et al. Construindo idéias sobre a juventude envolvida com a criminalidade violenta. Estud Pesqui Psicol [Internet]. 2010[citado 2013 fev. 21];10(2). Disponível em: http:// www.revispsi.uerj.br/v10n2/artigos/pdf/v10n2a10.pdf

14. Corradi-Webster CM, Esper LH, Pillon SC. A enfermagem e a prevenção do uso indevido de drogas entre adolescentes. Acta Paul Enferm. 2009;22(3):331-4.

15. Adorno RCF. Uso de álcool e drogas e contextos sociais da violência. SMAD Rev Eletr Saúde Mental Álcool Drog [Internet]. 2008[citado 2013 fev. 21];4(1). Disponível em: http:// www.revistas.usp.br/smad/article/view/38662/41509 
16. Ferreira RS, Aragão COM, Arruda A. "Boladão, pesadão, isso é Rio de Janeiro": notas sobre funks de torcida e de facção. Aletheia [Internet]. 2010 [citado 2013 fev. 21];(32):38-52. Disponível em: http://www.redalyc.org/ pdf/1150/115020838004.pdf

17. Rodriguez A, Ferreira RS, Arruda A. Representações sociais e território nas letras de funk proibido de facção. Psicol Rev (Belo Horizonte) [online]. 2011 [citado $2013 \mathrm{fev}$. 21];17(3):414-32. Disponível em: http://pepsic.bvsalud.org/ pdf/per/v17n3/v17n3a06.pdf

18. Feltran GS. Crime e castigo na cidade: os repertórios da justiça e a questão do homicídio nas periferias de São Paulo. Cad CRH [Internet]. 2010 [citado 2013 fev. 21];23(58). Disponível em: http://www.scielo.br/pdf/ccrh/v23n58/ v23n58a05.pdf
19. Heim J, Andrade AG. Efeitos do uso do álcool e das drogas ilícitas no comportamento de adolescentes de risco: uma revisão das publicações científicas entre 1997 e 2007. Rev Psiquiatr Clín [Internet]. 2008 [citado 2013 fev. 21];35 Supl.1:61-4. Disponível em: http://www.scielo.br/pdf/rpc/ v35s1/a13v35s1.pdf

20. Pfromm Netto S. Psicologia da adolescência. 6a ed. Brasília: Pioneira; 1977.

21. Souza J, Kantorski LP, Luis MAV, Oliveira NF. Intervenções de saúde mental para dependentes de álcool e outras drogas: das políticas à prática cotidiana. Texto Contexto Enferm [Internet]. 2012 [citado 2013 fev. 27];21(4):729-38. Disponível em: http://www.scielo.br/pdf/tce/v21n4/02.pdf

\section{Acknolegement}

To Fundação de Amparo à Pesquisa do Estado de São Paulo (FAPESP), for financial support of the study. Process n. 2012/19418-2. 